\title{
Farmers Adoption of Vetiver Grass Hedgerows for Soil and Water Conservation, Haru District, Western Ethiopia
}

\author{
Lemesa Hailu ${ }^{1, ~ *, ~ L e t a ~ H a i l u ~}$ \\ ${ }^{1}$ Sena Ghimbi Secondary High School, Ghimbi, Ethiopia \\ ${ }^{2}$ Jimma Agricultural Research Center, Jimma, Ethiopia
}

Email address:

lemesahailu12@gmail.com (L. Hailu)

${ }^{*}$ Corresponding author

\section{To cite this article:}

Lemesa Hailu, Leta Hailu. Farmers Adoption of Vetiver Grass Hedgerows for Soil and Water Conservation, Haru District, Western Ethiopia. Journal of Energy and Natural Resources. Vol. 10, No. 1, 2021, pp. 14-27. doi: 10.11648/j.jenr.20211001.12

Received: December 24, 2020; Accepted: January 7, 2021; Published: February 23, 2021

\begin{abstract}
Soil erosion is one of the most series problems for the agricultural sector in Ethiopia. There is a need to understand the effective soil and water conservation practices. Therefore, feasible, easy, socially acceptable and environmentally friendly soil conservation practice is essential in the study area due to existence of severe soil erosion. The objective of the study was to investigate the farmers' adoption of Vetiver grass hedgerows for soil and water conservation in Haru district, Western Ethiopia. The data were collected through questionnaire survey; FGD (Focus Group Discussion), KII (Key Informant Interview) and observation. Quantitative and qualitative sources of data were used for the study. Both primary and secondary types of data were also employed in this study. The quantitative data were analyzed with the help of SPSS version 20 and analyzed using descriptive statistics and Chi-square test. Whereas, the qualitative data were analyzed by descriptive narrations. Majority of respondents reported that soil erosion exists on their farmland at different degrees which hinders crop productivity. The study confirms that $71.3 \%$ of respondents practice Vetiver grass for soil and water conservation, whereas, $28.7 \%$ of respondents do not practice Vetiver grass for soil and water conservation. There is statistically significant association between knowledge of households and the use of Vetiver grass, which influences their willingness to practice. The study indicated that sex, age, educational status and family size of sample respondents have showed statistically significant association with farmers' practice of Vetiver grass for soil and water conservation. Whereas, marital status, source of income and farmland size have no significant association with the practice. Moreover, awareness creation among local community, facilitating training and initiating farmers on usage of Vetiver grass and experience sharing among users and other farmers within the kebele administration was suggested.
\end{abstract}

Keywords: Vetiver Grass, Soil and Water Conservation, Soil Erosion, Haru District

\section{Introduction}

Soil erosion is the most significant ecological restriction to sustainable agricultural production, mainly under subsistence agricultural production system like most part of Ethiopian highlands [1]. For instance, the study conducted on a preliminary soil loss and run off by Jimma Agricultural Research Center at Melko indicated that 82.3 tons per hectare of soil was eroded annually [2]. However, soil conservation programs in the highlands of Ethiopia were premised on the notion that farmers did not perceive erosion and had little or no interest in combating it for many years [3].
Soil conservation programs and approaches performed poorly until recently due to most soil conservation planning approaches rely on empirical assessment methods by experts and hardly consider farmer's knowledge of soil erosion [4]. Some technological packages of soil conservation particularly terracing is cumbersome, costly and hence is not appreciated by the farmers. This in turn resulted in low agricultural productivity, food insecurity and poverty [5]. However, the farmers are applying in different parts of the country and various conservation measures like soil bund, stone bund and other physical soil and water conservation are practiced and less emphasis was given for biological soil and water conservation. 
Unlike most physical measures that collapse with time, Vetiver grass strips are alive and self-adjusting and do not compete with neighboring crop plants [6]. Vetiver grass hedgerows are popularly accepted due to low cost, easy application, low maintenance and high performance in reducing soil erosion. It is the simplest method for controlling soil erosion today. Although the grass has been grown in many countries for decades for erosion control, little is known about the use of the plant [7]. Vetiver grass rows have been used intensively for soil conservation purpose and common method of transmitting intermittent flows and control erosion in agricultural areas. The grass serves to stabilize the body of a channel, consolidate the soil mass and check the movement of the soil particles along the channel [8].

According to Alemu, Vetiver grass hedgerows has been found to thrive under rainfall ranging from $300 \mathrm{~mm}$ to 3000 $\mathrm{mm}$ per annum. Ability to regrow rapidly after being affected by drought, frost, fire, saline and other adverse conditions when the adverse effects are removed. The deep root system makes the Vetiver grass plant extremely drought tolerant. Adaptability to a wide range of soil types such as shallow, rocky, acidic and saline soil. All these features of Vetiver grass make it more effective and preferable to practice in a wide range of area [9]. In context of Ethiopia, the effects of Vetiver grass hedgerows on soil erosion and water flooding were studied at Melko. The result indicated that Vetiver grass hedgerows was successful in reducing soil erosion and reducing runoff [10]. However, the mechanical measures are generally not accepted due to its high cost, repeated reconstruction and high maintenance.

Generally, soil erosion is the most immediate environmental problem facing the nation in general and the study area in particular at present time. For current problem of severe soil erosion relevant findings and sustainable methods that help to decrease runoff and reduce soil loss have always been a problem for farmers. Hence, establishing of Vetiver grass hedgerows for soil conservation measures is very important to conserve the soil and increase crop yields. The Vetiver grass hedgerow practice for soil and water conservation was not studied yet in the area. Therefore, the objective of the study was to identify farmers practice of Vetiver hedgerows and factors influencing adoption of Vetiver grass for soil and water conservation.

\section{Material and Methods}

Haru district is located in northern direction at about 24 $\mathrm{km}$ from Gimbi capital city of the zone, and about $465 \mathrm{~km}$ from Addis Ababa. Astronomically, Haru District is located between $8^{\circ} 52^{\prime}$ to $9^{\circ} 07^{\prime}$ North latitude and $35^{\circ} 36^{\prime}$ to $36^{\circ} 03^{\prime}$ East longitude. In its administrative boundary, it shares with Gimbi district in North, Nole Kaba district in South, Chewaqa and Meko in south East, Genji district in west and Homa district in the North West (Figure 1). The total area of Haru district is 55,082 hectares [11].

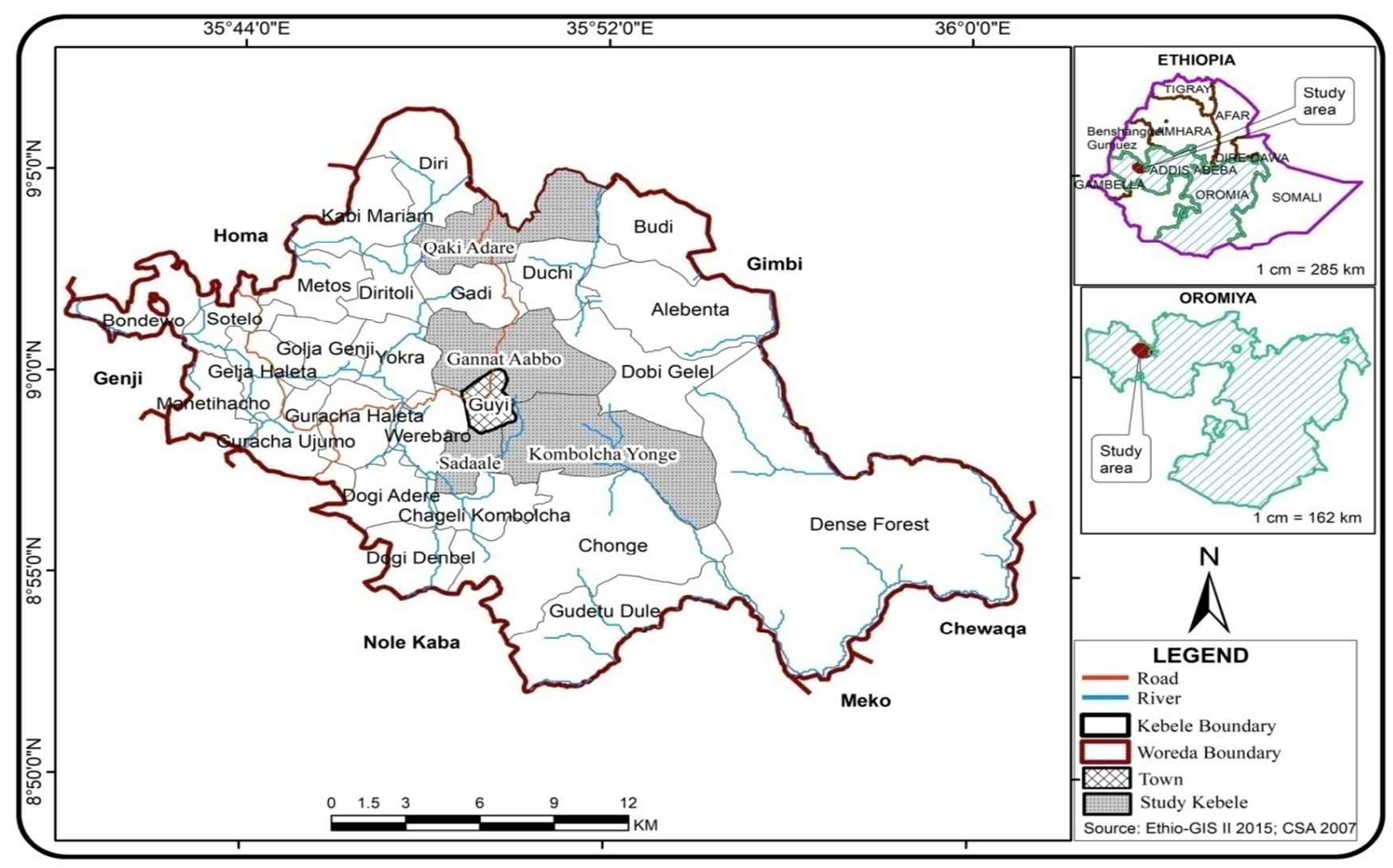

Source: Ethiopian Mapping Agency, 2017

Figure 1. The study map of Haru district. 


\subsection{Agro Ecology}

The district altitude is ranges between 1500 to 2050 meter above sea level. Plain area comprises 16,524.60 hectares, mountain 2, 754.10 hectare, rugged or dissected areas are about $11,016.46$ hectares and other is about 24,786.90 hectare (ibid). The agro-climatic zones of District, Lowland comprise about 8,097.054 hectare accounts for about $14.70 \%$ and midaltitude 46,984.946 hectare which accounts for about $85.30 \%$ of the district total land area. Nitosol is the dominat soil type of the area [11]. The district's minimum temperature is $12^{\circ} \mathrm{C}$ and maximum is $27^{\circ} \mathrm{C}$. The maximum annual temperature of $27^{\circ} \mathrm{C}$ occurs in December, January and February whereas $12^{\circ} \mathrm{C}$ minimum annual temperatures occurs in June, July and August. The mean annual rainfall of the study area is $1700 \mathrm{~mm}$. The maximum rainfall of the study area starts in May and extends to the end of October. In general, the study area experiences humid-hot climatic type [11].

\subsection{Socio-economic and Population Characteristics}

Livelihood: Agriculture is an important economic sector in Oromia region. The majorities of rural population live in the rural are engaged in agriculture as the source of livelihood. The major economic activity in the study area is a mixed agriculture, where production of crops and rearing of animals are undertaken. The major crops grown in the study area are maize, sorghum, teff, coffee and the main domestic animals reared at the study site are cattle, goat, sheep and donkey [11]

Population: The total population of Haru district is 67,262 of whom 33,178 were men and 34,084 were women. It comprises 13,332 households and urban dwellers are 4,870 out of the total population. In the aspect of their religions, the majority of the population are Protestant comprises of 72.09\%, Orthodox Christian accounts about $25.06 \%$ and $2.42 \%$ were Muslim [12]

\subsection{Research Design and Approach}

The research design used was cross-sectional study conducted in selected rural kebele administrations of the district. Moreover, the cross sectional design has capable of using data from a large number of population and focused on finding relationships between variables at one moment in time as well as measure differences among a variety of people, subjects, or phenomena rather than a process of change.

Research Approach: The mixed research approach was employed since a single research approach alone does not provide all necessary information on the research problem. The quantitative approach was used for data collected through questionnaire survey and qualitative approach for focus group discussions and key informant interviews.

\subsection{Data Types and Sources}

The data sources of the study were both qualitative and quantitative data. Both primary and secondary types of data was used. Focus group discussion and interviews also employed. The secondary types of data were including reports, journals, articles and books.

\subsection{Sampling Technique and Sample Size Determination}

The purposive sampling technique method was used. The three rural kebele administrations from Waina dega and one kebele from Bereha agro climatic zones were selected. Therefore, the samples of four rural kebeles administration namely, Ganat Aabbo, Kombocha Yonge, Sadaale and Qaki Adare which consist of 405, 559, 227 and 511 households, respectively from 26 kebeles of Haru district were used. Therefore, in order to determine sample size, the researcher applied (Yamane, 1967:886) cited in [13] simplified formula to calculate sample size.

$$
\mathrm{n}=\frac{\mathrm{N}}{1+\mathrm{N}(\mathrm{e})^{2}}
$$

Where, $\mathrm{n}$ is designates the sample size.

$\mathrm{N}$ is designates the population size of sample kebele. $\mathrm{e}$ is designates the level of precision that is 0.05 .

1 is designates the probability of the events occurring. Therefore, $\mathrm{N}=1702$

$$
\begin{gathered}
\mathrm{e}=0.05 \\
\mathrm{n}=? \\
\mathrm{n}=\frac{1702}{1+1702(0.05)^{2}} \mathrm{n}=\frac{1702}{1+1702(0.0025)} \\
\mathrm{n}=\frac{1702}{1+4.255} \\
\mathrm{n}=324
\end{gathered}
$$

\subsection{Data Collection Instrument and Methods}

Questionnaire: The questionnaire was used to collect first hand (primary data) information regarding household heads socio-economic and demographic characteristics, household heads perception on soil erosion, soil conservation and practice of Vetiver grass for soil and water conservation. Therefore, questionnaire was constructed properly based on the objectives of the study. The questionnaire was pretested on randomly selected few household heads, enumerators were trained and the final survey was administered.

Key Informant Interview: key informants were selected from different group of the social classes. These interviewees provided the researchers with information concerning soil and water conservation and practice of Vetiver grass for soil conservation including factors that hinder farmers from the use of Vetiver grass for soil conservation.

Focus Group Discussion (FGD): The discussion was made with two women, one model farmer, one youth and one Village leader in each kebele because they are believed to be familiar with the issue under investigation. The focus group discussions were handled using a checklist. The ideas of focus group discussion were written on paper. 
Field Observation: Field observation was conducted across farm plots and household heads' home before conducting the main survey to observe practice of Vetiver grass for soil conservation in sample kebeles of Haru district.

\subsection{Methods of Data Analysis}

To make analysis more convenient, the researcher edited the data which were collected from different angles. For correcting the data, the homogenous data were arranged in groups on the basis of common features. The researcher employed descriptive statistics for data analysis. The data which were obtained through questionnaire are quite fit for mathematical computation, were analyzed with the help of SPSS version 20.

Descriptive statistics like table, figure, frequency, percentage, mean, standard deviation, cross tabulation and chi-square test were also employed. Moreover, chi-square test was employed to identify the association between dependent and independent variables. In addition, the qualitative data were analyzed using researcher's judgment in terms of words and statements in a good manner.

\section{Results and Discussion}

\subsection{Demographic and Socio Economic Characteristics of the Sample Respondents}

The total number of household heads considered for the study was 321, which are selected from four different kebele's proportion to their total population through systematic random sampling. Accordingly, the largest proportion of household heads 104 (32.3\%) from Kombolcha Yoonge whereas 97(30.2\%), 77(23.9\%) and 43(13.3\%) from Kaki Adare, Ganat Aabboo and Sadaale kebeles respectively (Table 1).

Table 1. Distribution of sample respondents by their sample kebeles.

\begin{tabular}{|c|c|c|c|c|c|c|c|c|c|c|}
\hline & \multicolumn{10}{|c|}{ Rural kebeles administration } \\
\hline & \multicolumn{2}{|c|}{ Kombolcha Yonge } & \multicolumn{2}{|c|}{ Kaki Adare } & \multicolumn{2}{|c|}{ Ganat Aabbo } & \multicolumn{2}{|c|}{ Sadaale } & \multicolumn{2}{|c|}{ Total } \\
\hline & No & $\%$ & No & $\%$ & No & $\%$ & No & $\%$ & No & $\%$ \\
\hline Sample respondents & 104 & 32.3 & 97 & 30.2 & 77 & 23.9 & 43 & 13.3 & 321 & 100 \\
\hline Total & 104 & 32.3 & 97 & 30.2 & 77 & 23.9 & 43 & 13.4 & 321 & 100 \\
\hline
\end{tabular}

\subsection{Demographic Characteristics of the Sample Respondents}

The demographic characteristics of respondents were to be considered based on sex, age, family sizes and marital status of household heads.

Table 2. Distribution of respondents by their sex.

\begin{tabular}{|c|c|c|c|c|c|c|c|c|c|c|c|}
\hline \multirow{3}{*}{ Variable } & \multirow{3}{*}{ Categories } & \multicolumn{10}{|c|}{ Rural kebeles administrations } \\
\hline & & \multicolumn{2}{|c|}{ Kombolcha Yonge } & \multicolumn{2}{|c|}{ Kaki Adare } & \multicolumn{2}{|c|}{ Ganat Aabbo } & \multicolumn{2}{|c|}{ Sadaale } & \multicolumn{2}{|c|}{ Total } \\
\hline & & No & $\%$ & No & $\%$ & No & $\%$ & No & $\%$ & $\mathbf{N}$ & $\%$ \\
\hline \multirow{3}{*}{$\begin{array}{l}\text { Sex of } \\
\text { household heads }\end{array}$} & Male & 94 & 90.6 & 93 & 95.9 & 68 & 88.3 & 39 & 90.7 & 294 & 91.7 \\
\hline & Female & 10 & 9.1 & 4 & 4.1 & 9 & 11.7 & 4 & 9.3 & 27 & 8.3 \\
\hline & Total & 104 & 100 & 97 & 100 & 77 & 100 & 43 & 100 & 321 & 100 \\
\hline
\end{tabular}

According to (Table 2), out of the total sample respondents, $294(91.7 \%)$ households were those whose head is male while the left $27(8.3 \%)$ were household with women head. Among 94(90.6\%), 93(95.9\%) and 68 (88.3\%) from Kombolcha Yonge, Kaki Adare and Ganat Aabbo, respectively were male headed households. Sex of household head determines access to information and perception of soil erosion problem, and willingness and ability of household to decide on use of soil conservation practice [14]. Thus, the researcher may expect that male headed households have better access to information than female headed households that helps to decide on the use of soil conservation measures.

Table 3. Distribution of sample household heads by their age.

\begin{tabular}{|c|c|c|c|c|c|c|c|c|c|c|c|}
\hline \multirow{3}{*}{ Variable } & \multirow{3}{*}{ Category } & \multicolumn{10}{|c|}{ Rural kebeles administrations } \\
\hline & & \multicolumn{2}{|c|}{ Kombolcha Yonge } & \multicolumn{2}{|c|}{ Kaki Adare } & \multicolumn{2}{|c|}{ Ganat Aabbo } & \multicolumn{2}{|c|}{ Sadaale } & \multicolumn{2}{|c|}{ Total } \\
\hline & & No & $\%$ & No & $\%$ & No & $\%$ & No & $\%$ & $\mathbf{N}$ & $\%$ \\
\hline \multirow{5}{*}{$\begin{array}{l}\text { Age of household } \\
\text { heads }\end{array}$} & $24-30$ & 17 & 16.0 & 21 & 21.4 & 18 & 23.4 & 9 & 20.9 & 65 & 20.2 \\
\hline & $31-45$ & 61 & 58.5 & 50 & 51.0 & 41 & 53.2 & 21 & 48.8 & 173 & 53.8 \\
\hline & $46-60$ & 21 & 20.8 & 20 & 21.4 & 11 & 14.3 & 10 & 23.3 & 62 & 19.3 \\
\hline & $61-66$ & 5 & 4.7 & 6 & 6.1 & 7 & 9.1 & 3 & 7.0 & 21 & 6.5 \\
\hline & Total & 104 & 100 & 97 & 100 & 77 & 100 & 43 & 100 & 321 & 100 \\
\hline $\mathrm{SD}$ & 10.37 & & & & & & & & & & \\
\hline Minimum & 24 & & & & & & & & & & \\
\hline Maximum & 66 & & & & & & & & & & \\
\hline
\end{tabular}


As it can be seen in table 3, the largest proportion of household heads, around 53.8\% are from age group (31-45), with small proportion of old age households (6.5\%). This survey result shows that almost $93.3 \%$ sample respondents were economically active age groups which could have a positive implication on the practice of Vetiver grass for soil conservation. Age of household is another important variable which can influence the practice of Vetiver grass for soil conservation. It was found that the youngest household head was aged 24 and the eldest 66 years. The mean age of household was 40.68 with standard deviation of 10.37. Age of a household head plays a significant role in household decision on the use of different types of soil and water conservation technologies.

Table 4. Distribution of respondents by marital status.

\begin{tabular}{|c|c|c|c|c|c|c|c|c|c|c|c|}
\hline \multirow{3}{*}{ Variable } & \multirow{3}{*}{ Categories } & \multicolumn{10}{|c|}{ Rural kebeles administrations } \\
\hline & & \multicolumn{2}{|c|}{ Kombolcha Yonge } & \multicolumn{2}{|c|}{ Kaki Adare } & \multicolumn{2}{|c|}{ Ganat Aabbo } & \multicolumn{2}{|c|}{ Sadaale } & \multicolumn{2}{|c|}{ Total } \\
\hline & & No & $\%$ & No & $\%$ & No & $\%$ & No & $\%$ & $\mathbf{N}$ & $\%$ \\
\hline \multirow{5}{*}{$\begin{array}{l}\text { Marital status } \\
\text { of household } \\
\text { heads }\end{array}$} & Single & 5 & 4.7 & 3 & 3.1 & 6 & 7.8 & 1 & 2.3 & 15 & 4.6 \\
\hline & Married & 87 & 80.2 & 86 & 87.6 & 61 & 75.3 & 37 & 81.4 & 271 & 84.4 \\
\hline & Divorced & 3 & 2.8 & 2 & 2.1 & 3 & 3.9 & 1 & 2.3 & 9 & 2.8 \\
\hline & Widowed & 9 & 12.3 & 6 & 7.2 & 7 & 13.0 & 4 & 14.0 & 26 & 8 \\
\hline & Total & 104 & 100 & 97 & 100 & 77 & 100 & 43 & 100 & 321 & 100 \\
\hline
\end{tabular}

Married household's accounts about $84.4 \%$, while the left $15.6 \%$ are single, divorced and widowed. This survey result shows that almost $85 \%$ of selected household heads were married. Therefore, the married households are expected to practice more (Table 4).

Table 5. Distribution of respondents by their family size.

\begin{tabular}{|c|c|c|c|c|c|c|c|c|c|c|c|}
\hline \multirow{3}{*}{ Variable } & \multirow{3}{*}{ Categories } & \multicolumn{10}{|c|}{ Rural kebeles administrations } \\
\hline & & \multicolumn{2}{|c|}{ Kombolcha Yonge } & \multicolumn{2}{|c|}{ Kaki Adare } & \multicolumn{2}{|c|}{ Ganat Aabbo } & \multicolumn{2}{|c|}{ Sadaale } & \multicolumn{2}{|c|}{ Total } \\
\hline & & No & $\%$ & No & $\%$ & No & $\%$ & No & $\%$ & $\mathbf{N}$ & $\%$ \\
\hline \multirow{5}{*}{$\begin{array}{l}\text { Family size of } \\
\text { household } \\
\text { heads }\end{array}$} & $2-3$ & 12 & 11.3 & 16 & 16.5 & 7 & 9.1 & 4 & 9.3 & 39 & 12.2 \\
\hline & $4-5$ & 63 & 60.4 & 52 & 53.6 & 42 & 54.5 & 17 & 39.5 & 174 & 54.2 \\
\hline & $6-7$ & 24 & 23.6 & 24 & 24.7 & 22 & 28.6 & 18 & 41.9 & 88 & 27.4 \\
\hline & $8-9$ & 5 & 4.7 & 5 & 5.2 & 6 & 7.8 & 4 & 9.3 & 20 & 6.2 \\
\hline & Total & 104 & 100 & 97 & 100 & 77 & 100 & 43 & 100 & 321 & 100 \\
\hline Mean & 5.38 & & & & & & & & & & \\
\hline SD & 1.758 & & & & & & & & & & \\
\hline Max. & 9 & & & & & & & & & & \\
\hline Min. & 2 & & & & & & & & & & \\
\hline
\end{tabular}

Table 5 illustrate that out of the total sampled households $54.2 \%$ of them have a family size $4-5$ whereas $27.4 \%$ have $6-$ 7 and the remaining $12.2 \%$ and $6.2 \%$ have $2-3$ and $8-9$, respectively. The household family size of the total sampled with mean and standard deviation of 5.38 and 1.758 persons respectively. Family size of households was found to be an important and determinant variable of Vetiver grass practice which can determine the amount of the labor force in the household. Households with larger work force may invest more in conservation practice which is considered more effective and efficient by the household. Family size, which can determine the amount of the labor force in the household, is expected to bring about variation in decision behavior of households as to which soil and water conservation measures to use [14]. Therefore, economically active members of family can positively influence the practice of Vetiver grass for soil conservation. Therefore, the large family size households are expected to practice Vetiver grass more.

\subsection{Socio-economic Distribution of Sample Respondents}

The socio-economic characteristics of survey respondents were to be considered based on educational background, level of income, occupation and source of income.

Table 6. Distribution of respondents by their educational status.

\begin{tabular}{|c|c|c|c|c|c|c|c|c|c|c|c|}
\hline \multirow{3}{*}{ Variable } & \multirow{3}{*}{ Categories } & \multicolumn{10}{|c|}{ Rural kebeles administrations } \\
\hline & & \multicolumn{2}{|c|}{ Kombolcha Yonge } & \multicolumn{2}{|c|}{ Kaki Adare } & \multicolumn{2}{|c|}{ Ganat Aabbo } & \multicolumn{2}{|c|}{ Sadaale } & \multicolumn{2}{|c|}{ Total } \\
\hline & & No & $\%$ & No & $\%$ & No & $\%$ & No & $\%$ & $\mathbf{N}$ & $\%$ \\
\hline \multirow{5}{*}{$\begin{array}{l}\text { Educational } \\
\text { status of hhhs }\end{array}$} & Illiterate & 52 & 50.0 & 56 & 57.7 & 36 & 46.8 & 24 & 55.8 & 168 & 52.3 \\
\hline & Elem.(1-6) & 24 & 22.6 & 26 & 26.8 & 20 & 26.0 & 11 & 25.6 & 81 & 25.2 \\
\hline & Elem.(7-8) & 23 & 21.7 & 11 & 131. & 19 & 24.7 & 6 & 14.0 & 59 & 18.3 \\
\hline & Sec.\& above & 5 & 5.6 & 4 & 4.1 & 2 & 2.6 & 2 & 4.7 & 13 & 4 \\
\hline & Total & 104 & 100 & 97 & 100 & 77 & 100 & 43 & 100 & 321 & 100 \\
\hline
\end{tabular}


Educational status of household heads was considered as one of the most important variable of the study. Due to the fact that, education is one of the important variables, which increases farmer's ability to acquire process and use information relevant to the practice of Vetiver grass hedgerows for soil conservation.

The portion of households that who are neither able to read nor able to write accounts about $52.3 \%$ where $25.2 \%$ and $18.3 \%$ of elementary (grade 1-6) and grade 7-8 completed households respectively. However, the number of households who have completed secondary and above is relatively very small that is only $4 \%$ (Table 6). Education level influence decision level of the farmers towards adoption of the different conservation measures [15].

Table 7. Distribution of respondents by their monthly income and source of income.

\begin{tabular}{|c|c|c|c|c|c|c|c|c|c|c|c|}
\hline \multirow{3}{*}{ Variable } & \multirow{3}{*}{ Categories } & \multicolumn{10}{|c|}{ Rural kebeles administrations } \\
\hline & & \multicolumn{2}{|c|}{ Kombolcha Yonge } & \multicolumn{2}{|c|}{ Kaki Adare } & \multicolumn{2}{|c|}{ Ganat Aabbo } & \multicolumn{2}{|c|}{ Sadaale } & \multicolumn{2}{|c|}{ Total } \\
\hline & & No & $\%$ & No & $\%$ & No & $\%$ & No & $\%$ & $\mathbf{N}$ & $\%$ \\
\hline \multirow{4}{*}{$\begin{array}{l}\text { Main source } \\
\text { income of hhhs }\end{array}$} & Coffee & 65 & 60.4 & 53 & 54.6 & 37 & 48.1 & 26 & 60.5 & 181 & 56.3 \\
\hline & Crop & 38 & 38.7 & 44 & 45.4 & 40 & 51.9 & 17 & 39.5 & 139 & 43.3 \\
\hline & Animal & 1 & 0.9 & & & & & & & 1 & 0.3 \\
\hline & Total & 104 & 100 & 97 & 100 & 77 & 100 & 43 & 100 & 321 & 100 \\
\hline \multirow{3}{*}{$\begin{array}{l}\text { Monthly } \\
\text { income of hhhs } \\
\text { in Birr }\end{array}$} & $601-1200$ & 17 & 17.2 & 35 & 36.1 & 30 & 39.0 & 22 & 51.2 & 104 & 32.4 \\
\hline & $1201-1800$ & 2 & 1.9 & 5 & 5.2 & 7 & 9.1 & 2 & 4.7 & 16 & 4.9 \\
\hline & Total & 104 & 100 & 97 & 100 & 77 & 100 & 43 & 100 & 321 & 100 \\
\hline
\end{tabular}

The major source of income and average monthly income of selected households, almost all the households have two main source of the income are Coffee production (56.3\%) and crop production $(43.3 \%)$, while their average income per month is relatively very small, 201 households $(62.6 \%)$ of them earn the average monthly income of less than 600 Ethiopian birr, which shows that the economic status of household is very poor (Table 7). Household heads with high income are capable of investing in conservation measure whereas; household heads with low income abstains from mobilizing resources for improving the environment [16].

The source of income and monthly income were the major socio-economic variable used to explain the background of the respondents. With respect to the major source of income and average monthly income of selected households, almost all the households have two main source of the income that is crop and coffee production.

Table 8. Distribution of respondents by their occupation.

\begin{tabular}{|c|c|c|c|c|c|c|c|c|c|c|c|}
\hline \multirow{3}{*}{ Variable } & \multirow{3}{*}{ Categories } & \multicolumn{10}{|c|}{ Rural kebeles administrations } \\
\hline & & \multicolumn{2}{|c|}{ Kombolcha Yonge } & \multicolumn{2}{|c|}{ Kaki Adare } & \multicolumn{2}{|c|}{ Ganat Aabbo } & \multicolumn{2}{|c|}{ Sadaale } & \multicolumn{2}{|c|}{ Total } \\
\hline & & No & $\%$ & No & $\%$ & No & $\%$ & No & $\%$ & $\mathbf{N}$ & $\%$ \\
\hline \multirow{3}{*}{$\begin{array}{l}\text { Occupati on of } \\
\text { household } \\
\text { heads }\end{array}$} & Farmer & 101 & 97 & 93 & 95.9 & 73 & 94.8 & 42 & 97.6 & 309 & 96.2 \\
\hline & Others & 3 & 2.9 & 4 & 4.1 & 4 & 5.2 & 1 & 2.4 & 12 & 3.8 \\
\hline & Total & 104 & 100 & 97 & 100 & 77 & 100 & 43 & 100 & 321 & 100 \\
\hline
\end{tabular}

Table 8 indicated the main occupation of household heads of the sample respondents. Accordingly, 97\%, 95.9\%, 94.8\% and $97.6 \%$ of the sample households were from Kombolcha Yonge, Kaki Adare, Ganat Aabboo and Sadaale Kebeles respectively have said that they are farmers. The overall percentages of respondents $(96.2 \%)$ were farmers. Only a little proportion actually $3.8 \%$ from the four kebeles was engaged in different economic activities as primary economic activities and farming as secondary means of livelihood.

\subsection{Means of Land Acquisition and Farmland Size of Sample Respondents}

Land is a primary source of livelihood for all rural household heads. Having large farm size can potentially lay a sound base for a farmer household heads and facilitate sufficient ground to apply combination of new farming packages [17]. Farm activities, particularly crop and coffee production which is the main economic activities of the study area require primarily the availability of suitable farmland. In the study area land is one of the necessary constraints of the households because the newly formed households have no option to get their own farmlands elsewhere except sharing from their parents.

Table 9. Distribution of respondents by their means of land acquisition and farmland size.

\begin{tabular}{lllll}
\hline No & Variables & Categories & Frequency & Percent \\
\hline \multirow{4}{*}{1} & How you get & Inheritance & 198 & 61.7 \\
& the land & From the government & 51 & 15.8 \\
& & Gift & 72 & 22.5 \\
& & Total & 321 & 100.0 \\
\multirow{3}{*}{2} & Total size of & $1-3$ & 129 & 40.2 \\
& your farmland & $3.1-5$ & 145 & 45.1 \\
& in Hectar & 5 and above & 41 & 12.8 \\
& & Total & 6 & 1.9 \\
\hline
\end{tabular}

As it can be inferred from Table $9,61.7 \%$ of sample households have got farmland through inheritance whereas $22.5 \%$ has got through gift and the remaining $15.8 \%$ from the 
government.

As far as the land holding size of the farmers concerned, there is a significant variation among the size of the land in the study area. Of the sampled households, $45.1 \%$ have a farmland size of 1-3 hectares followed by $40.2 \%$ of respondents which have less than 1 hectare and the remaining have $12.8 \%$ and $1.9 \%$ have $3.1-5$ and 5 and above hectares respectively.

\subsection{Landownership and Practice of Vetiver Grass for Soil Conservation}

Landownership has its own impact on the practice of soil conservation. Accordingly, the result of field survey revealed that out of the total sample respondents $211(65.4 \%)$ of respondents answered as the landownership has impact on the practice of Vetiver grass while the remaining 110 (34.6\%) responded as landownership has no impact on the practice of Vetiver grass for soil conservation. We can conclude that land ownership has impact on the practice of Vetiver grass hedgerows for soil conservation.

\subsection{Association of Farmers' Practice of Vetiver Grass with Demographic and Socio-economic Variables}

\subsubsection{Association of Farmers' Practice of Vetiver Grass with Demographic Variables}

In order to identify the association of household heads' Vetiver grass practice with important demographic, socioeconomic variables, this study employs cross tabulation statistics and chi-square test of association.

Among the total number of household heads covered in this study, $92(28.7 \%)$ of household heads did not practice Vetiver grass methods, whereas the majority 229 (71.3\%) practiced Vetiver grass for soil conservation. According to (Tables 10, 11), a significant variation in proportion of household heads practicing Vetiver grass with respect to demographic characteristics.

For instance, the proportion of household heads practicing Vetiver grass, as it can be seen in Table 10, differs by sex of household heads. More than seventy percent $(73.5 \%)$ of the male household heads were practicing Vetiver grass, whereas the proportion of women household heads practicing and not practicing Vetiver grass was founded to be nearly equal. This result implies as men household heads are more dedicated to accept advice and support rendered by experts. Statistical test of association, chi-square test calculated for this association were founded to be, $\chi 2=7.75, \mathrm{p}=0.005$, which supporting the significant association of sex of household heads with their practice of Vetiver grass hedgerows for soil conservation.

The status of household heads on Vetiver grass practice considerable varies across different age category of farmers participated in this study. The highest number of household head practicing the Vetiver grass method was observed among age group of $24-30$ years $(83.1 \%)$ followed by $31-45$ years (72.8\%) and age group 46-60 years (65\%)- the result that shows, willingness of the economical active age groups to accept new strategy, especially Vetiver grass practice is high.
The chi-square test of association computed to assess the association of age category of respondents confirms as there is strong relationship between age of respondents' and their participation on Vetiver grass practice. As it can be seen from the cross tabulation between age category and household heads status of Vetiver grass hedgerows for soil conservation, young and adult age households, from 24-30 and 31-45 were founded to be more committed household heads in adopting these techniques than other age category. The result of chisquare calculated was, $\chi^{2}=10.923, \mathrm{P}=0.002$, the findings which reveals significant association of willingness and ability to practice Vetiver grass with age of household heads.

This study is in line with [18-20], who found out that age has a negative effect on conservation decisions, especially on Vetiver grass usage of farmers, the willingness and participation of using new conservation strategies of environment decreases as they get old and old. However, this study is inconsistent with previous study conducted by [21] in Lay Armachiho district, who reported has no statistically significant at level of 0.05 between age of farmers and practice of Vetiver grass for soil conservation.

Table 10. Distribution of respondents by their sex and age with the use of Vetiver grass.

\begin{tabular}{|c|c|c|c|c|c|c|}
\hline \multirow{3}{*}{ Background } & \multicolumn{4}{|c|}{ Do you practice VG } & \multirow{3}{*}{$x^{2}$} & \multirow{3}{*}{ P-value } \\
\hline & \multicolumn{2}{|c|}{ Yes } & \multicolumn{2}{|l|}{ No } & & \\
\hline & $\mathbf{N}$ & $\%$ & $\mathbf{N}$ & $\%$ & & \\
\hline \multicolumn{7}{|l|}{ Sex } \\
\hline Male & 216 & 73.5 & 78 & 26.5 & \multirow{3}{*}{7.75} & \multirow{3}{*}{$0.005^{*}$} \\
\hline Female & 13 & 48 & 14 & 51.9 & & \\
\hline Total & 229 & 71.3 & 92 & 28.7 & & \\
\hline \multicolumn{7}{|l|}{ Age category } \\
\hline $24-30$ & 54 & 83.1 & 11 & 16.7 & \multirow{5}{*}{10.923} & \multirow{5}{*}{$0.002 *$} \\
\hline $31-45$ & 126 & 72.8 & 47 & 27.2 & & \\
\hline $46-60$ & 38 & 65.3 & 25 & 39.7 & & \\
\hline $61-66$ & 11 & 55 & 9 & 45 & & \\
\hline Total & 229 & 71.3 & 92 & 28.7 & & \\
\hline
\end{tabular}

Note - *shows the calculated chi-square value is significant at $5 \%$ level of significance

According to Table 11, marital status of a household heads under consideration is also seen as important variable for using Vetiver grass. Among the respondents (household heads), about $86.7 \%$ of the single household heads, $71.8 \%$ of married household heads and $88.8 \%$ of divorced household heads were practice Vetiver grass, while the percentage of widowed household heads practicing Vetiver grass were founded less, $(57.1 \%)$ compared to other category.

In addition to major difference seen with respect to Vetiver grass practice by different categories of marital status, the test result also confirms as marital status of household heads determine their capacity to employ this method. Mainly, the computed chi-square value for this variable was founded to be, $\chi^{2}=6.551, \mathrm{P}=0.088$ ), showing considerable dependence between marital and veitver grass practice status of the households. This result dictates the less participation of widowed household in using Vetiver grass, may be due to lack of supports; moral and cooperation either from family or couple and then affecting their socio-economic status. 
The family size of household heads was an important and determinant variable of Vetiver grass practice for this study. As indicated in (Table 11), the highest number of household heads practicing the Vetiver grass method was observed among family size 6-7 (76.9\%) and 4-5 (71.9\%) household heads were leading the practice Vetiver grass. while the percentage of household head with family size of 2-3 practicing Vetiver grass was founded less, (48.4\%) compared to other category. The association of family size with practicing the Vetiver grass was also assessed by using statistical test of association. The result of this test statistics support the evidence obtained from the cross tabulation (Table 11), and implying as there is strong significant association between family size and practice of Vetiver grass hedgerows for soil conservation were observed that is $\chi^{2}$ $=10.132, \mathrm{P}=0.017$. This result is in line with [22] who obtained significant regression result between adoption of soil and water conservation technologies and family size.

Table 11. Marital status and family size of respondents with use of Vetiver grass.

\begin{tabular}{|c|c|c|c|c|c|c|}
\hline \multirow{3}{*}{ Background } & \multicolumn{4}{|c|}{ Do you practice Vetiver grass } & \multirow[t]{3}{*}{$x^{2}$} & \multirow[t]{3}{*}{ P-value } \\
\hline & \multicolumn{2}{|c|}{ Yes } & \multicolumn{2}{|c|}{ No } & & \\
\hline & $\mathbf{N}$ & $\%$ & $\mathbf{N}$ & $\%$ & & \\
\hline \multicolumn{7}{|l|}{ Marital status } \\
\hline Single & 13 & 86.7 & 2 & 13.3 & & \multirow{5}{*}{0.088} \\
\hline Married & 188 & 71.8 & 74 & 28.2 & & \\
\hline Divorced & 8 & 88.8 & 1 & 11.1 & 6.55 & \\
\hline Widowed & 20 & 57.1 & 15 & 42.85 & 1 & \\
\hline Total & 229 & & 92 & & & \\
\hline \multicolumn{7}{|l|}{ Family size } \\
\hline $2-3$ & 13 & 48.4 & 15 & 53.6 & & \multirow{5}{*}{0.017} \\
\hline $4-5$ & 123 & 71.9 & 48 & 28.1 & & \\
\hline $6-7$ & 83 & 76.9 & 25 & 23.1 & 10.1 & \\
\hline $8-9$ & 10 & 71.4 & 4 & 28.6 & 32 & \\
\hline Total & 229 & & 92 & & & \\
\hline
\end{tabular}

\subsubsection{Association of Farmers' Practice of Vetiver Grass with Socio-economic Variables}

The association of farmers' practice of Vetiver grass hedgerows for soil conservation was tested with socioeconomic variables as follows. Among the important socioeconomic variable considered, educational levels, income levels and occupation of household heads was founded to be important determinant for using Vetiver grass, while, source of income and farm land size owned by the household heads were founded insignificant. (Tables 12, 13).

Table 6 portrays that the portion of households that who are neither able to read nor able to write accounts about $52.3 \%$ where $25.2 \%$ and $18.3 \%$ of elementary (grade 1-6) and grade 7-8 completed households respectively. However, the number of households who have completed secondary and above is relatively very small that is only 4\%. Yitayal et al. 2004 found a positive relationship between education and the decision to use conservation measures [15]. Therefore, farmers who are better in educational status are expected to have more likely hood to practice Vetiver grass for soil conservation.

With regard to educational level, household heads who are neither able to read nor able to write were founded less likely to practice Vetiver grass $(60.8 \%)$ and those attend primary education ( grade 1-6), were founded less likely to practice Vetiver grass, with low percentage of practicing of Vetiver grass $78 \%$, while more than eighty percent of households who have at least complete grade eight, (86.4\%) and about $92.3 \%$ of household heads with secondary and above level were practicing Vetiver grass for soil conservation purpose. The result obtained from chi-square test of association $\left(\chi^{2}=\right.$ $20.527, \mathrm{P}=0.000)$, also strongly supports this linkage of education level with usage of Vetiver grass by farmers. This significant chi-square value justifies the strong association between household heads level of education and their interest (efforts) to employ Vetiver grass in order to save their land from erosion. This test statistics result reveals that at least completing primary school would help household heads in changing their attitude, identifying the impact of new technologies on their daily life, inquiring necessary guidance from concerned bodies, and then improving their way of life. This study is in agreement with the study conducted by [21, 23] who reported that, statistically there was a significant difference between different education levels in the adoption of Vetiver grass as a technique for soil and water conservation. This showed that educated farmers were more willing to adopt new technologies than the non-literate ones hence, the adoption of Vetiver grass were done by literates.

Concerning the occupation of the selected household heads, which is the basic income of households, all most all of the household heads investigated $(96.2 \%)$ were household heads that are primarily living on farming activities. The remaining $3.8 \%$ were primarily engaged on different economic activities but also they engaged in agricultural activities as secondary means of livelihood (Table 8). This result implies as farmer's household heads (those engaged in agricultural activities as primary source of income) were more practice Vetiver grass $(72.8 \%)$ than others. The result of chi-square calculated was, $\chi^{2}=1.031, \mathrm{P}=0.310$, the findings reveals insignificant association of willingness and ability to practice Vetiver grass with occupation of household heads

Table 12. Educational level and occupation of respondents with use of Vetiver grass.

\begin{tabular}{|c|c|c|c|c|c|c|}
\hline \multirow{3}{*}{ Background } & \multicolumn{4}{|c|}{ Do you practice VG } & \multirow{3}{*}{$x^{2}$} & \multirow{3}{*}{ P-value } \\
\hline & \multicolumn{2}{|c|}{ Yes } & \multicolumn{2}{|c|}{ No } & & \\
\hline & $\mathbf{N}$ & $\%$ & $\mathbf{N}$ & $\%$ & & \\
\hline \multicolumn{7}{|l|}{ Educational level } \\
\hline Illiterate & 102 & 60.8 & 65 & 39.2 & & \\
\hline Elementary (1-6) & 64 & 78 & 18 & 22 & & \\
\hline Ele. School(7-8) & 51 & 86.4 & 8 & 13.6 & 20.527 & $0.000 *$ \\
\hline Secondary and above & 12 & 92.3 & 1 & 7.7 & & \\
\hline Total & 229 & 71.3 & 92 & 28.7 & & \\
\hline \multicolumn{7}{|l|}{ Occupation } \\
\hline Farmer & 225 & 72.8 & 84 & 27.2 & & \\
\hline Others & 4 & 44.4 & 5 & 55.6 & 1.031 & 0.310 \\
\hline Total & 229 & 71.3 & 92 & 28.7 & & \\
\hline
\end{tabular}

Note- VG: Veiver Grass; * shows the calculated chi-square value is significant $5 \%$ level of significance

With respect to the average monthly income of the household heads included in this study, large portion of them are living are poor, more than sixty percent $(67.7 \%)$ are household heads getting less than 600 per month. Out of the 201 total household 
who have monthly income of less than 600 , about $32.3 \%$ were not using Vetiver grass, while more than eighty percent (81.3\%) of households having average monthly income of more than 1200 were founded to be user of Vetiver grass. This result shows as the economic status of farmers (household heads) in this study area is highly affecting or hindering their efforts of overcoming the poverty. Besides, the above cross tabulation result, test of association (chi-square), was founded to be 8.684, with $\mathrm{p}$ value 0.008 , confirming as there is significant association between the level of income and participation of households on Vetiver grass practice. This result agreed with the findings of [22, 24], who reported the influence of wealth status on the application of soil conservation practices.

Unlike the independent variables discussed above; source of household head income and farm land size, was founded to be insignificant. Out of these farmers; farmers that are living by only crop cultivation are founded to be slightly more user of Vetiver grass (73.3\%), while $68.6 \%$ of households cultivating coffee use Vetiver grass. However, the result of statistical test of association (chi-square value, 1.27, $\mathrm{p}=0.528$ ), the findings which reveals insignificant association of willingness and ability to practice Vetiver grass with source of income of household heads.

Similar to major source of income of household heads, farm land size owned by each household heads were founded to be insignificant factors to determine the usage of Vetiver grass. With respect to land size, most of them, about $46 \%$ do have an average land size of 1-3 hectare, followed by less than one hectare $(40.2 \%)$, and then 3-5 hectare per household $(12.8 \%)$ (Table 9). However, more than eighty percent $(83.3 \%)$ of respondents those practice Vetiver grass (VG) were those have 5 and above hectares.

The calculated chi-square value for farm land size with Vetiver grass practice was, $\chi 2=1.450, \mathrm{p}=0.694$, justifying as they do not have influence on practicing the Vetiver grass in the study area.

Table 13. Source of income, monthly income and farmland size of respondents with use of Vetiver grass $(V G)$.

\begin{tabular}{|c|c|c|c|c|c|c|}
\hline \multirow{3}{*}{ Background } & \multicolumn{4}{|c|}{ Do you practice VG } & \multirow{3}{*}{$x^{2}$} & \multirow{3}{*}{ P-value } \\
\hline & \multicolumn{2}{|c|}{ Yes } & \multicolumn{2}{|c|}{ No } & & \\
\hline & $\mathbf{N}$ & $\%$ & $\mathbf{N}$ & $\%$ & & \\
\hline \multicolumn{7}{|c|}{ Major Source of income } \\
\hline Coffee & 132 & 73.3 & 48 & 26.7 & \multirow{4}{*}{1.276} & \multirow{4}{*}{0.528} \\
\hline Crop & 96 & 68.6 & 44 & 31.4 & & \\
\hline Livestock & 1 & 0.0 & & & & \\
\hline \multicolumn{5}{|c|}{ Monthly Income } & & \\
\hline Less than 600 & 136 & 67.7 & 65 & 32.3 & \multirow{3}{*}{8.684} & \multirow{3}{*}{$0.008 *$} \\
\hline $601-1200$ & 80 & 76.9 & 24 & 23.1 & & \\
\hline $1201-1800$ & 13 & 81.3 & 3 & 18.8 & & \\
\hline \multicolumn{5}{|c|}{ Farm land size in hectare } & \multirow{5}{*}{1.450} & \multirow{5}{*}{0.694} \\
\hline$<1$ & 92 & 70.7 & 38 & 29.2 & & \\
\hline $1-3$ & 106 & 73.1 & 39 & 26.8 & & \\
\hline $3-5$ & 26 & 65 & 14 & 35 & & \\
\hline 5 and above & 5 & 83.3 & 1 & 16.6 & & \\
\hline
\end{tabular}

\subsection{Impacts of Household Perception, Attitude and Soil Erosion Level on the Practice of Vetiver grass for Soil Conservation}

Farmers' decisions to retain conservation structures are positively and significantly related to soil erosion perceptions attitude towards new technology and exposure to new practices. Therefore, it is important to know household perception and attitude on soil erosion.

\subsubsection{Level of Household Heads Awareness on Vetiver Grass Adoption}

It is well known by any household that soil erosion is primarily caused by their land use practices. Likewise, the success of any soil intervention depends on the extent to which the introduced conservation measures are accepted and adopted by the farming community. In other words, acceptance and farm-level practice of the newly introduced conservation measures by the households is the decisive element for the success of soil conservation activities. Accordingly, as Vetiver grass is new methods of soil conservation in the study area, the level of household awareness, understanding and acceptance of methods determine the effectiveness of the methods. Concerning this specific study; attitude and knowledge of farmers towards the use of Vetiver grass for soil conservation was assessed. The result obtained from the survey depicts as there is knowledge gap in importance of this method. This knowledge gap is due to different factors like, detail awareness about the use of Vetiver grass and lack of detail training.

For example, the result of cross tabulation of Table 14 shows as large portion of households do have information about Vetiver grass, more than ninety percent $299(93.1 \%)$ of household have at least heard about the Vetiver grass, of which seventy percent $229(71.3 \%)$ only practicing the Vetiver grass currently. This shows as there is lack of teaching the farmers, creating awareness, and practically showing how it works. Statistical test of association, the chi-square value for this variable justifies also as there is strong relation between the level of awareness and their willing to adopt this method (Chi-square value, 22.432, $\mathrm{P}=.000$ ). This survey finding shows dictates as awareness creation and knowledge transfer on importance of Vetiver grass and how to practice is very important.

Table 14. Cross tabulation of Vetiver grass (VG) awareness versus practice of Vetiver grass.

\begin{tabular}{|c|c|c|c|c|c|}
\hline \multirow[t]{2}{*}{ Do you know VG } & \multicolumn{2}{|c|}{$\begin{array}{l}\text { Do you practice VG } \\
\text { for soil conservation }\end{array}$} & \multirow[t]{2}{*}{ Total } & \multirow[t]{2}{*}{$x^{2}$} & \multirow[t]{2}{*}{ P-value } \\
\hline & Yes & No & & & \\
\hline Yes & 223 & 76 & 299 & & \\
\hline No & 6 & 16 & 22 & 22.432 & .000 \\
\hline Total & 229 & 92 & 321 & & \\
\hline
\end{tabular}

\subsubsection{Household Heads Knowledge and Attitude on Level of Soil Erosion}

The result from the selected household respondents on their awareness on land erosion, the level of current land erosion, conservation methods in relation with their status of Vetiver grass practice was also assessed to know the extent of land erosion and methods they have been using so far. Specifically, the association of household heads response on existence of soil erosion, the degree (extent) of soil erosion in study area and the household head Vetiver grass practice is tested using chi-square test of independence (Table 15). Accordingly, test 
statistics result of Table 15, shows a strong association between household head understanding of soil erosion on their land and use of Vetiver grass (chi-square of 4.569, $\mathrm{P}=0.033$ ). Additionally, the association between the extent (severity) of land erosion and use of Vetiver grass has been founded significant (chi-square of $13.135, \mathrm{P}=0.004$ ). This result also depicts as household participation on using Vetiver grass for soil conservation depends on their attitude of land erosion on their farm land. Farmers' perception of soil erosion is a key social factor that is also important in deciding options for controlling soil losses [25]. Therefore, farmers' perception and attitudes towards soil erosion and conservation practices is decisive in protecting soil losses from erosion.

Table 15. Household heads knowledge and attitude on level of soil erosion.

\begin{tabular}{|c|c|c|c|c|c|}
\hline \multirow{2}{*}{ No } & \multirow{2}{*}{ Variable } & \multicolumn{2}{|c|}{ Use of Vetiver grass } & \multirow{2}{*}{$x^{2}$} & \multirow{2}{*}{ P-value } \\
\hline & & Yes & No & & \\
\hline \multirow{3}{*}{1} & \multicolumn{4}{|c|}{ Do you believe soil erosion exist on your farmland } & 0.033 \\
\hline & Yes & 212 & 78 & 4.569 & \\
\hline & No & 17 & 14 & & \\
\hline \multirow[t]{5}{*}{2} & \multicolumn{4}{|c|}{ How you describe the severity of land erosion } & \\
\hline & Very high & 66 & 17 & & \\
\hline & High & 112 & 37 & 13.135 & 0.004 \\
\hline & Low & 48 & 34 & & \\
\hline & I do not know & 3 & 4 & & \\
\hline
\end{tabular}

The information obtained from Survey participants in group discussion and the key informants also respond as soil erosion exists on their farmland. The impact of soil erosion also increased from time to time that can be observed from the decline of productivity of their farm land. The soil was more eroded than ever before mainly due to different human activities. Therefore, it needs appropriate and effective soil conservation method. The farmers use different measures of soil conservation practices like terracing, mulching, strip cultivation and etc to reduce problem of soil erosion on their farm land.

\subsection{Major Soil Conservation Practiced in the Study Area}

The major soil conservation techniques practiced in the study area. The result of field survey depicts that Vetiver grass hedgerows were not fully practiced by farmers for soil conservation in the study area. Accordingly, out of the total sample respondents $229(71.3 \%)$ of respondents were using Vetiver grass hedgerows for soil conservation. This is followed by terracing which accounts $47(14.6 \%)$ and other, crop rotation and manuring accounts almost 45(13\%) together (Figure 2).

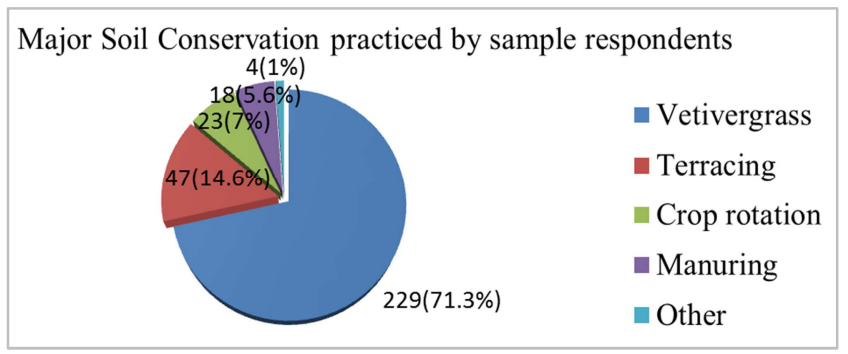

Figure 2. Major soil conservation practiced by respondents.

\subsubsection{Reasons for Preferring Vetiver Grass Hedgerows for Soil Conservation}

As it has been discussed in 3.5, household heads in this study area has been using different technologies, for saving their land and securing production. Among these different techniques commonly practiced most of them are practicing Vetiver grass alone or Vetiver grass with other methods. According to Table 16 Vetiver grass preference of household heads for soil conservation is due to different advantages of Vetiver grass compared to others methods. Especially, the result of this survey shows as Vetiver grass is simple and easy techniques that requires less labor force, does not require regular maintenance once it's planted, it is efficient to reduce erosion and preserving the soil moisture

Similarly, different studies conducted in Ethiopia showed the importance of Vetiver grass in conserving soil. It's a relatively low cost erosion and sediment control technology with very high benefit/cost ratio. For instance, in Ethiopia at Melko the effects of Vetiver hedges on runoff and soil erosion were studied. The study was found that it was successful in reducing runoff and limiting soil movement, resulting in very little erosion [10]

Table 16. Reasons for preferring Vetiver grass hedgerows for soil conservation.

\begin{tabular}{|c|c|c|c|c|}
\hline No & Variables & Responses & Frequency & Percent \\
\hline \multirow[t]{7}{*}{1} & Reason for preferring VGHR & Easy to use and require less labor & 78 & 34.06 \\
\hline & & Reduce more erosion & 117 & 51.09 \\
\hline & & preserve soil moisture & 21 & 9.17 \\
\hline & & No need of regular maintenance & 11 & 4.8 \\
\hline & & No compute nutrients with other & 1 & 0.4 \\
\hline & & Need less labour when planted & 1 & 0.4 \\
\hline & & Total & 229 & 100.0 \\
\hline
\end{tabular}

VGHR: Vetiver Grass Hedge Rows

Table 16, indicates that out of the total respondents 117 $(51.09 \%)$ of respondents were prefer Vetiver grass to reduce more erosion whereas, $78(34.06 \%)$ and $21(9.17 \%)$ of them preferring due to its easy to use and require less labor and preserve soil moisture respectively, the remaining about $5 \%$ of respondents were preferring Vetiver grass due to no need of regular maintenance and no compute nutrients. This result shows as majority of respondent prefer Vetiver grass for reducing soil erosion. Vetiver grass is a very simple, practical, inexpensive, low maintenance and very effective means of soil and water conservation, sediment control, land stabilizations and rehabilitation [26]. 


\subsubsection{Farmland Coverage by Vetiver Grass Hedgerows Users}

In the study area, it is widely used for reducing soil erosion, preserving soil moisture and rehabilitating deteriorated farm land. The farmland covered by Vetiver grass was not uniform among different farmlands. Moreover, the degree of farmers practicing Vetiver grass for soil conservation in the study area was mainly based on the awareness of Vetiver grass and perception of soil erosion.

Table 17. Distribution of respondents'farmland coverage by Vetiver grass (VG) users.

\begin{tabular}{|c|c|c|c|c|}
\hline No & Variables & Responses & Frequency & Percent \\
\hline \multirow[t]{6}{*}{1} & Farmland covered by VG & All of farmland & 5 & 2.2 \\
\hline & & $3 / 4$ of farm land & 21 & 9.2 \\
\hline & & Half of farmland & 66 & 28.8 \\
\hline & & $1 / 4$ of farm land & 133 & 58.1 \\
\hline & & Less than $1 / 4$ of farmland & 4 & 1.7 \\
\hline & & Total & 229 & 100.0 \\
\hline \multirow{4}{*}{2} & Locality & To improve soil fertility & 94 & 41.0 \\
\hline & & Terrace formation & 16 & 7.0 \\
\hline & & Mulching material & 2 & .9 \\
\hline & & Total & 229 & 100.0 \\
\hline
\end{tabular}

As indicated in Table 17, out of the total respondents 133 $(58.1 \%)$ of respondents covered $1 / 4$ of their farmland by Vetiver grass while $66(28.8 \%)$ and $21(9.2 \%)$ of respondents were covered their farmland by half and three fourth, respectively. The remaining $5(2.2 \%)$ of respondents were covered all of their farm land by Vetiver grass. This survey result shows that majority of respondents almost more than fifty percent of respondents were covered one fourth of their farmland by Vetiver grass.

The same Table 17 also indicates the purpose of using Vetiver grass hedgerows in the study area. Accordingly, out of the total respondents $117(51.1 \%)$ of respondents were using Vetiver grass to reduce surface runoff. Whereas, 94 $(41.0 \%)$ and $16(7.0 \%)$ of respondents were using Vetiver grass hedgerows to improve soil fertility and terrace formation respectively. The remaining 2 (0.9\%) of respondents were for mulching purpose. For instance, the study conducted by on coffee based cropping system in Wichi area of Illubabor indicated that, Vetiver grass hedgerow was effective in reducing the soil loss during the third cropping season [27].

\subsubsection{Technical Supports and Organizations That Provide on the Practice of Vetiver Grass}

Farmers need technical support to use Vetiver grass effectively for soil conservation. In addition to technical support, information is one of the most important parameters, which help the farmers to become aware of a Vetiver system. It plays a vital role in adoption process of Vetiver grass. Through this, farmers can understand the advantages of the new technology. It can initiate farmers to test the Vetiver grass practice on their own farmland.

Table 18. Distribution of Respondents’ Technical Support and Providing Organization.

\begin{tabular}{|c|c|c|c|}
\hline 1 & Do you get technical support on VG & Frequency & Percent \\
\hline & Yes & 218 & 95.2 \\
\hline & No & 11 & 4.8 \\
\hline Total & & 229 & 100 \\
\hline \multirow[t]{3}{*}{2} & Which Organization that provide technical support & Frequency & Percent \\
\hline & WAO & 162 & 70.7 \\
\hline & HARSC & 64 & 27.9 \\
\hline Total & & 229 & 100 \\
\hline
\end{tabular}

VG: Vetiver grass; WAO: Woreda Agricultural Office; HARC: Haru Agricultural Research Sub-Center; AGP II : Agricultural Growth Program

Based on significant impact of Vetiver grass justified by other studies, currently government has been giving due attention and escalating the practice of this environmental protection. The support provided by government includes training the farmers, facilitating the provision of Vetiver grass and supervision of outcomes. For example, in this study area large portion of farmers', $218(95.2 \%)$ of farmers currently practicing Vetiver grass hedgerows have been getting the technical support from professional (experts), (Table 18), while 11 households $(4.8 \%)$ has been using this method without the support. Thus, the present study is in line with $[28,29]$ who reported positive correlation between conservation decision and extension contact.

As indicated in Table 18, out of the total sample of the study population $162(70.7 \%)$ of respondents got this technical support from district agricultural office whereas, 64 $(27.9 \%)$ and $3(1.3 \%)$ of respondents mainly from Haru Agricultural Sub-Research Center and the other respectively. 
During face-to-face interview with key informants, they responded as the research center contribute significant role in the dissemination of Vetiver grass throughout the district. Additionally, the research center also provides different training for development agents on soil and water conservation at different times. At the beginning the research center distributes Vetiver grass for farmers without payments. Now a day's, Vetiver grass is used for soil conservation on crop and coffee farmland in the study area.

\subsubsection{Outcomes After Adoption of Vetiver Grass for Soil Conservation}

The following tabulate data indicates change observed after practice of Vetiver grass hedgerows and factors that motivate to practice Vetiver grass hedgerows for soil conservation.

Table 19. Outcomes after practice of Vetiver grass for soil conservation.

\begin{tabular}{|c|c|c|c|}
\hline Variables & Categories & Frequency & Percentage \\
\hline \multirow{5}{*}{$\begin{array}{l}\text { Observed change on farm land after practice of } \\
\text { VGHR }\end{array}$} & The farmland is developed to bench terrace & 40 & 17.46 \\
\hline & Increased crop yield & 96 & 41.9 \\
\hline & Decreased erosion/soil mov’t & 92 & 40.1 \\
\hline & Preserve soil moisture & 1 & 0.43 \\
\hline & Total & 229 & 100 \\
\hline \multirow{4}{*}{$\begin{array}{l}\text { Factors that motivate to practice Vetiver grass } \\
\text { for soil conservation }\end{array}$} & Reduction of productivity of the soil & 95 & 41.48 \\
\hline & Erosion by running water & 117 & 51.09 \\
\hline & Degradation & 2 & 0.87 \\
\hline & Total & 229 & 100 \\
\hline
\end{tabular}

VGHR: Vetiver Grass Hedge Rows,

As indicated in (Table 19), the change observed after practice of Vetiver grass hedgerows for soil conservation and factors that motivate farmers to practice Vetiver grass hedgerows for soil conservation. Accordingly, out of the total sample respondents 96 (41.9\%) of respondents responded as they observed Vetiver grass increase crop yield whereas, 92 $(40.1 \%)$ and $40(17.46 \%)$ of respondents were observed the decreased erosion/soil movement and farm land developed into bench terrace respectively. On the other hand, motivation of household heads is very important to implement a new soil conservation practices in study areas. Having this reality in mind, $117(51.09 \%)$ respondents motivated to practice Vetiver grass due to the severity of erosion by running water whereas, $95(41.48 \%)$ and $15(6.5 \%)$ of respondents responded as motivated by reduction of production/productivity of the soil and termite effects respectively. This survey result shows as majority of respondents were motivated to adopt Vetiver grass due to the severity of erosion by running water.

\subsubsection{Reasons for Non-user of Vetiver Grass for Soil Conservation}

The result of this study and other related to finding of [30], who justified importance of using Vetiver grass for soil conservation. However, currently Vetiver grass use is not fully practiced in the study area. There are different factors that influence non-users of Vetiver grass from practicing it for soil conservation in the study area.

Table 20. Reasons of non-user of Vetiver grass for soil conservation.

\begin{tabular}{lll}
\hline Main reason of non-user of Vetiver grass (VG) & Frequency & Percent \\
\hline VG decrease farm land & 8 & 8.69 \\
Shortage of Vetiver grass for plantation & 24 & 26.08 \\
lack of human labor & 38 & 41.30 \\
Lack of awareness about VG & 21 & 22.82 \\
Other & 1 & 1.08 \\
Total & 92 & 100 \\
\hline
\end{tabular}

Vetiver grass is the effective and easy measures of soil conservation but not fully practiced in the study area. Table 20, indicates that out of the total sample population, $92(28.7 \%)$ of respondents were not practice Vetiver grass hedgerows for soil conservation due to different reason. Among which, 38(41.30\%) of respondents do not practice due to shortage of human labor whereas $24(26.08 \%)$ and $21(22.82 \%)$ due to shortage of Vetiver grass and lack of awareness respectively, the remaining $8(8.69 \%)$ of respondents mainly due to the perception that Vetiver grass reduce (consume) farm land. This shows that majority of non-user were due to shortage of human labor and lack of awareness about Vetiver grass.

\section{Conclusions}

The farmers of the study area agreed on the existence of soil erosion and had been using different soil and water conservation practices. The study result revealed the association between the extent of land erosion and use of Vetiver grass has been founded significant. In addition, farmers in the study area, practice different soil conservation measures to conserve soil on their farm land. However, the study result revealed that $229(71.3 \%)$ of respondents were practice Vetiver grass whereas, 92(28.7\%) of respondents were not practice Vetiver grass for soil conservation. The 
study result confirms that farmer's practice of Vetiver grass for soil and water conservation has strong association with respondent's sex, age, educational status, family size, monthly income and occupation. However, source of income, marital status and farmland size of respondents has no statistically significant influence on the practice of Vetiver grass for soil conservation. The result of cross tabulation on Vetiver grass awareness versus practice of Vetiver grass is also significant with $\chi 2^{\prime}=22.432$, p-value 0.000 . The chisquare test founded significant result among household head knowledge and attitude on level of soil erosion that is $\chi 2^{\prime}$ $=13.135, \mathrm{p}$-value 0.004 . The result of this study and other related articles, has justified importance of using Vetiver grass for soil and water conservation. Farmers in this study area have been using different soil conservation measures for saving their land and securing production. Among these different techniques commonly practiced most of them are practicing Vetiver grass. Majority 117 (51.09\%) of respondents prefer Vetiver grass for its potential in reducing erosion by running water.

The result of the study clearly indicates that, out of the total sample population, $92(28.7 \%)$ of respondents were not practice Vetiver grass hedgerows for soil conservation. Among, $38(41.30 \%)$ of respondents do not practice due to shortage of human labor whereas $24(26.08 \%)$ and $21(22.82 \%)$ due to shortage of Vetiver grass and lack of awareness respective. As stated by farmer's response, focus group participants and key informants, the main determinant factors for the farmer's practice of Vetiver grass for soil conservation were related with demographic and socio-economic variables. As well as farmer's perception of soil erosion and awareness on Vetiver grass was another factor which hinders the farmer's practice of Vetiver grass in the study area. Therefore; awareness creation among the local community and arrange experience sharing among adopter and non-adopter farmers on the role of Vetiver grass hedgerows on soil and water conservation is essential. Moreover, establishing different Vetiver grass nursery site and increasing its availability within the district through active participation is important to increase availability of the grass. Furthermore, to understand the biophysical and socio economic effect of the Vetiver grass further research is suggested.

\section{References}

[1] Z. Gete, and H. Hurni, Implications of Land Use and Land Cover Dynamics for Mountain Resource Degradation in the Northwestern Ethiopian Highlands: Journal of Mountai Research and Development, 2001, 22, 184-191.

[2] K. Tesfu, and M. Zebene, Effect of Different Cover Crops on Runoff and Soil Loss. Proceeding: Workshop organized by UNESCO chair in water resources entitled "International Sediment Initiatives Conference (ISIC)”, Nov. 12-15, 2006, Khartoum.

[3] A. Mekuria, Forest conversion-soil degradation-farmers' perception nexus: implications for sustainable land use in the southwest of Ethiopia. 2005, Göttingen, Germany
[4] G. Yohannes, and K. Herweg, From indigenous knowledge to participatory technology development: Centre for Development and Environment (CDE), 2000, University of Bern.

[5] K. Menale, H. Stein, K. Gunnar, and B. Randy, Economics of Soil Conservation Adoption in High-Rainfall Areas of the Ethiopian Highlands. 2008, Environment for Development.

[6] R. G. Grimshaw, Vetiver and the Environment. The Second International Conference on Vetiver, 2000, Thailand.

[7] O. Babalola, J. C. Jimba, O. Maduakolam, and O. A. Dada, Use of Vetiver grass for Soil and water conservation in Nigeria. Proc. Third Intern. Conf. on Vetiver and Exhibition. P 293-309. Guangzhou, China, October 2003.

[8] Taffa Tullu (2011) Soil and water conservation for sustainable agriculture, Mega publishing and Distribution P. L. C Addis Ababa, 2011.

[9] M. Alemu, Hand Book on Vetiver grass technology: From Propagation to utilization. For Ethiopia, GTZ -IFSP South Gondar, Ethiopia, Waste Usamba Mountains. Published PhD Thesis, Wageningen University, Netherlands, 2000.

[10] Y. Tesfaye, K. Tesfu and E. Solomon, Soil and Water Conservation under Coffee based Cropping Systems. In Girma Adugna, Bayetta Bellachew, Tesfaye Shimber, Endale Taye, and Taye Kufa (eds.). 2007, Coffee diversity and knowledge. EIAR, Addis Ababa, Ethiopia.

[11] Haru District Agricultural Organization, Annual Report. Haru, 2016.

[12] Central Statistical Agency, Annual Report, Haru, Addis Ababa, Ethiopia, 2007.

[13] M. Yilma, Measuring rural household food security status and its determinants in Benshangul Gumuz Region Ethiopia: The case of Assosa District. An M.Sc Thesis presented to the School of Graduates of Alemaya University, Alemaya, 2005, $147 \mathrm{pp}$, Unpublished.

[14] Z. M. Semgalawe, Household Adoption Behaviour and Agricultural sustainability in the Northern Mountains of Tanzania: The case of soil conservation in the North pares, 1999.

[15] A. Yitayal, B. Ayalneh, and H. G. Abebe, Determinants of Use of Soil Conservation Measures by Smallholders in Jimma Zone: The Case of Dedo District. An MSc. Thesis presented to the School of Graduate Studies of Alemaya University, 2004. 65-82p.

[16] D. Alemneh, Integrated Natural Resources Management to Enhance Food Security: The Case of Community-based Approach in Ethiopia. Environment and Natural Resource Service Research, Extension and Training Division FAO sustainable Development Department, 2003, FAO of UNS, Rome.

[17] D. Bekele, The status of community participation in the rehabilitation of degraded land. A case study of shebedino district, sidama zone, southern Ethiopia, 2014.

[18] A. Aklilu, Caring for the land Best practices in soil and water conservation in Beressa watershed highlands of Ethiopia. Ph.D. thesis, 2016, Wageningen University, Netherlands

[19] G. E. Tegegne, Willingness to pay for Environmental Protection: an application of contingent valuation method (CVM) in Sekota District, Northern Ethiopia, Ethiopian Journal of agricultural Economics, 1999, 3: 123-130 
[20] S. Girmachew, Determinants of adoption of soil and water conservation practices in the environs of simen mountains national park, Ethiopia, 2005.

[21] Y. Jigar, The status of Vetiver grass as a technique for soil and water conservation in Lay Armachiho district Department of Natural Resource Management, 2016, University of Gondar, Gondar, Ethiopia.

[22] T. Million, and B. Kassa Belay, Factors influencing Adoption of Soil Conservation Measures in Southern Ethiopia: The Case of Gununo Area, Journal of Agriculture and Rural Development in the Tropics and Subtropics Volume 105, No.1, 2004, pages 49-62.

[23] T. A. K. Nzeribe, and I. Nwachukwu. Use of Vetiver grass in the control of Erosion in Anambra state, Nigeria. Environmental Research Journal 2(6): 317-321, 2008

[24] T. Elni, Continued Use of Soil and Water Conservation Practices: a Case study in Tulla District, Ethiopia, MSc Thesis, Wageningen University, 2008.

[25] J. D. Graaff, Soil conservation and sustainable land use: An economic approach Royal Tropical Institute, Amsterdam. Ethiopia: The agricultural sector: an overview, 1993, vol. 2 and 1, FAO, Rome.
[26] Sustainable Land Use Forum (SLUF), Best practices in Vetiver system application for soil and water conservation, recycling coffee pulp, agro-forestry and area closure, Addis Ababa, Ethiopia. 2010, Pp. 54.

[27] H. Afework, Vetiver System Contribution for Wetland Rehabilitation in Ethiopia: The Case of Wichi Wetland and Micro Watershed, Metu District, 2014.

[28] N. Asfaw, G. Kisan, M. Wilfered, and S. Beyene, Factors affecting adoption of maize production technologies in Bako area, Ethiopia. Ethiopian Journal of Agricultural Economics, 1997, 2: 52-73.

[29] F. Derajew, F. Bekabil, and B. Wagayehu, Determinants of the Use of Soi Conservation Technologies by Smallholder Farmers: The Case of Hulet Eju Enesie District, East Gojjam Zone, Ethiopia. Asian Journal of Agriculture and Food Sciences, 2013, 01 (04): 119-138.

[30] N. Tekalign, Farmers' Perception on the Role of Vetiver Grass in Soil and Water Conservation in South Western Ethiopia: The Case of Tulube Peasant Association; Metu District, Addis Ababa, Ethiopia November, 2011. 